JURNALYOGA DAN KESEHATAN

JURUSAN YOGA KESEHATAN

FAKULTAS BRAHMA WIDYA

IHDN DENPASAR
Vol. 3 No. 1 Maret 2020

ISSN : 2621-0185 (Cetak)

http://ejournal.ihdn.ac.id/index.php/jyk

\title{
Alasan Ibu Hamil HIV Positif Tidak Melanjutkan Perawatan PPIA Komprehensif dalam Aspek Layanan Kesehatan
}

\author{
Putu Emy Suryanti ${ }^{1}$, I Wayan Nerta ${ }^{2}$ \\ Institut Hindu Dharma Negeri Denpasar \\ email:emysuryanti@ihdn.ac.id, wayannerta10@gmail.com
}

Diterima tanggal 4 November 2019, diseleksi tanggal 3 Desember 2019, dan disetujui tanggal 22 Desember 2019

\section{ABSTRACT:}

Prevention of mother to child transmission (PMTCT)is a government program aimed at preventing mother-to-child transmission of HIV.One of the comprehensive PMTCT program is HIV testing for all pregnant women and advanced therapy for all pregnant women whose test results are positive.The Government's target is 100\% of HIV-positive pregnant women must be continuing the comprehensive PMTCT program, meanwhile there are HIV-positive pregnant women who discontinue the comprehensive PMTCT program.This study aims to explore the reasons of HIV-positive pregnant women to discontinue with the comprehensive PMTCT program. This study was a qualitative study through in-depth interviews with seven informants, namely : one HIV-positive pregnant woman whodiscontinue comprehensive PMTCT program, two HIV-positive women who gave birth the previous yearwhodiscontinue comprehensive PMTCT program, three public health centre (PHC) providers, and one head of PHC. Informants were selected using a purposive sampling technique. Data analysis was conducted thematically and the results were presented narratively to explore the reasons of HIV-positive pregnant women to discontinue with the comprehensive PMTCT program. Health care aspects of service readiness include the availability of PMTCT facilities and infrastructure, communication and attitudes of health providers in PMTCT program, waiting times for PMTCT program delivery, and assistance in PMTCT comprehensive program. Health care aspects of service readiness that are less than optimal can affect the understanding and desire of HIVpositive pregnant women to access comprehensive PMTCT program so that HIV-positive pregnant women discontinue comprehensive PMTCT program.

Keywords: pregnant women, HIV-positive, comprehensive PMTCT

\section{ABSTRAK:}

Pencegahan Penularan HIV dari Ibu ke Anak (PPIA) merupakan program Pemerintah untuk mencegah penularan HIV dari ibu ke anak. Salah satu kegiatan program PPIA komprehensif adalah pelaksanaan tes HIV untuk semua ibu hamil dan terapi lanjutan bagi semua ibu hamil dengan hasil tes positif. Target Pemerintah adalah $100 \%$ ibu hamil dengan HIV positif harus melanjutkan perawatan PPIA komprehensif, sementara masih ada ibu hamil HIV positif yang tidak melanjutkan perawatan PPIA secara komprehensif. Penelitian ini bertujuan untuk mengetahui secara mendalam mengapa ibu hamil HIV positif tidak melanjutkan perawatan PPIA komprehensif. Penelitian ini merupakan penelitian kualitatif melalui wawancara mendalam pada tujuh informan yaitu satu orang ibu hamil HIV positif yang tidak melanjutkan perawatan PPIA komprehensif, dua orang ibu HIV positif yang melahirkan 0-12 bulan terakhir dimana saat hamil tidak melanjutkan perawatan PPIA komprehensif, tiga petugas puskesmas, dan satu kepala puskesmas. Pemilihan informan menggunakan teknik purposive sampling. Analisis data dilakukan secara tematik dan hasil disajikan secara naratif untuk mengetahui mengapa ibu hamil HIV positif tidak melanjutkan perawatan PPIA komprehensif. Secara garis besar, aspek kesiapan layanan meliputiketersediaan sarana dan prasarana layanan PPIA, komunikasi dan sikap petugas kesehatan dalam layanan PPIA, waktu tunggu pemberian pelayanan PPIA, dan pendampingan dalam pelayanan PPIA. Aspek kesiapan layananyang kurang optimal dapat mempengaruhi pemahaman dan keinginan ibu hamil HIV positif untuk mengakses layanan PPIA komprehensifsehingga menyebabkan ibu hamil HIV positif tidak melanjutkan perawatan PPIA komprehensif.

Kata kunci: ibu hamil, HIV positif, PPIA komprehensif 


\section{PENDAHULUAN}

Terdapat peningkatan proporsi HIV/AIDS pada perempuan di Indonesia sekitar $28 \%$. Jumlah kasus AIDS pada anak-anak yang tertular HIV/AIDS dari ibunya juga meningkat yaitu sejumlah 48 kasus pada tahun 2004 menjadi 912 kasus hingga Bulan Juni 2012 (Kemenkes RI, 2014). Berdasarkan data tersebut, Pemerintah menerbitkan Peraturan Menteri Kesehatan Republik Indonesia No. 51 tahun 2013 tentang Pedoman Pencegahan dan Penularan HIV dari Ibu ke Anak (Kemenkes RI, 2013).Program PPIA mulai dilaksanakan di Indonesia tahun 2004. Hingga tahun 2012, cakupan program PPIA masih rendah yaitu 6\% (Dirjen Bina Gizi dan KIA, 2012). Untuk meningkatkan cakupan layanan, maka pelaksanaan program PPIA diintegrasikan dalam layanan kehamilan di seluruh puskesmas di Indonesia (Kemenkes RI, 2013). Alasan pelaksanaan integrasi program PPIA dalam layanan kehamilan (ANC) adalah karena cakupan ANC di Indonesia cukup tinggi yaitu 97\%, sementara cakupan pelayanan PPIA (termasuk pengobatan ARV) masih rendah (Kemenkes RI, 2017). PPIA mencakup 28.314 ibu hamil yang melakukan konseling dan melaksanakan tes HIV dimana 812 orang diantaranya positif, sementara yang mendapat ARV sejumlah 685 ibu hamil. Sehingga masih ada 127 ibu hamil HIV positif yang belum mendapatkan perawatan lanjutan atau belum mendapatkan layanan PPIA secara komprehensif (Kemenkes RI, 2012). Padahal salah satu target cakupan PPIA adalah ibu hamil yang telah dites HIV dan terdeteksi HIV positif saat pemeriksaan kehamilan, $100 \%$ harus mendapatkan terapi lanjutan (Dirjen Bina Gizi dan KIA, 2012), sehingga penting untuk mengetahui mengapa ibu hamil HIV positif tidak melanjutkan perawatan PPIA komprehensif.

Kabupaten Badung merupakan salah satu kabupaten di Provinsi Bali yang memiliki enam kecamatan, yaitu Kecamatan Petang, Kecamatan Abiansemal, Kecamatan Mengwi, Kecamatan Kuta, Kecamatan Kuta Utara, dan Kecamatan Kuta Selatan. Terdapat 13 puskesmas yang tersebar pada enam kecamatan tersebut, antara lain: Puskesmas Petang I, Puskesmas Petang II, Puskesmas Abiansemal I, Puskesmas Abiansemal II, Puskesmas Abiansemal III, Puskesmas Abiansemal IV, Puskesmas Mengwi I, Puskesmas Mengwi II, Puskesmas Mengwi III, Puskesmas Kuta Utara, Puskesmas Kuta I, Puskesmas Kuta II, dan Puskesmas Kuta Selatan. Badung merupakan salah satu kabupaten di Provinsi Bali yang memiliki angka kejadian HIV/AIDS yang cukup tinggi. Hingga tahun 2016 tercatat jumlah kumulatif kasus HIV/AIDS di Kabupaten Badung sebanyak 2.546 kasus atau sekitar 16,1\%. Berdasarkan survei awal peneliti yang dilakukan pada Bulan Agustus 2017, jumlah ibu hamil HIV positif dan ibu HIV positif yang telah melahirkan 0-12 bulan terakhir dimana saat hamil tidak melanjutkan perawatan PPIA komprehensif ditemukan di wilayah Kabupaten Badung. Penelitian ini dilaksanakan di tiga Puskesmas yaitu Puskesmas Petang I, Puskesmas Petang II, dan Puskesmas Mengwi II yang 
memiliki kasus ibu hamil HIV positif dan ibu HIV positif yang telah melahirkan 0-12 bulan terakhir dimana saat hamil tidak melanjutkan perawatan PPIA komprehensif.

\section{METODOLOGI}

Jenis penelitian yang digunakan adalah penelitian kualitatif, yang dilakukan dengan wawancara mendalam pada tujuh informan yang terdiri dari satu orang ibu hamil HIV positif yang tidak melanjutkan perawatan PPIA komprehensif, dua orang ibu HIV positif yang melahirkan 0-12 bulan terakhir dimana saat hamil tidak melanjutkan perawatan PPIA komprehensif, tiga petugas puskesmas, dan satu kepala puskesmas. Informan dipilih dengan prosedur purposive sampling sesuai dengan kriteria penelitian. Kriteria penelitian yaitu ibu hamil HIV positif yang tidak melanjutkan perawatan PPIA komprehensif, ibu HIV positif yang

melahirkan 0-12 bulan terakhir dimana saat hamil tidak melanjutkan perawatan PPIA komprehensif, dan bersedia menjadi informan penelitian.Wawancara dilakukan oleh penulis dengan menggunakan pedoman wawancara mendalam sesuai dengan tujuan penelitian. Dilakukan proses wawancara mendalam kemudian dibuatkan transkripnya, serta digabungkan dengan catatan peneliti selama pengumpulan data di lapangan dan disimpan dalam satu dokumen.

Analisis data dilakukan dengan mengolah transkrip hasil wawancara, membuat kode terhadap kata atau kalimat untuk memudahkan menganalisis informasi yang diperoleh dari informan satu dengan informan yang lainnya. Hasil analisis data disajikan menggunakan narasi atau uraian sesuai dengan pola yang ditemukan. Pengecekan keabsahan dilakukan dengan teknik triangulasi sumber. Penelitian ini telah mendapatkan kelaikan etik dari Komisi Etik Fakultas Kedokteran Universitas Udayana - RSUP Sanglah Denpasar.

\section{PEMBAHASAN}

Hasil penelitian disajikan berdasarkan perspektif aspek kesiapan layanan PPIA yang menggambarkan mengapa ibu hamil HIV positif tidak melanjutkan perawatan PPIA komprehensif. Penelitian ini menggunakan Field Theory atau Teori Medan sebagai kerangka kerja untuk mengetahui alasan ibu hamil HIV positif tidak melanjutkan perawatan PPIA komprehensif dari aspek kesiapan layanan PPIA.

Aspek kesiapan layanan PPIA meliputi: ketersediaan sarana dan prasarana layanan PPIA, komunikasi dan sikap petugas dalam memberikan layanan PPIA, waktu tunggu untuk mendapatkan layanan PPIA, serta pendampingan dalam pelaksanaan layanan PPIA. 


\subsection{Ketersediaan Sarana dan Prasarana dalam Layanan PPIA}

Sarana dan prasarana puskesmas khususnya fasilitas fisik puskesmas dalam menyediakan layanan PPIA dari sudut pandang para informan secara garis besar dikatakan sudah bagus dan sudah lengkap.

"Fasilitasnya yaa sudah bagus"

(Pernyataan informan R-01)

"Ampun lengkap nike (sudah lengkap)"

(Pernyataan informan R-02)

Sementara dari sudut pandang petugas puskesmas, masih terdapat beberapa hal dalam sarana dan prasarana puskesmas terkait layanan PPIA yang perlu ditingkatkan.

“Kadang-kadang terlambat di reagennya, pernah artinya seperti itu paling berapa minggu ada

(Pernyataan Petugas Puskesmas Petang I)

Selain sarana dan prasarana fisik, kebutuhan SDM kesehatan dalam layanan PPIA juga masih perlu ditingkatkan seperti yang disampaikan oleh petugas puskesmas di bawah ini terkait minimnya jumlah konselor. Puskesmas saat ini memiliki total lima orang konselor yang bersertifikat konselor.

"Kita punya LKB dua orang sekaligus sudah konselor, ada perawat satu, bidan satu, dan dokter satu" (Pernyataan Petugas Puskesmas Petang II)

Pernyataan serupa juga disampaikan oleh kepala puskesmas yang menyebutkan masih banyak bidan yang melaksanakan pemeriksaan ANC terintegrasi belum mengikuti pelatihan konselor. Puskesmas Petang I hanya memiliki dua orang bidan yang telah mengikuti pelatihan konselor.

"Bidan di sini juga yang sering periksa ANC integrasi itu juga belum semua punya sertifikat konselor. Jadi yang punya sertifikat konselor baru dua orang bidannya, jadi sebenarnya kami masih memerlukan pelatihan konselor lebih banyak lagi untuk bidan-bidan terutama di sini"

(Pernyataan Kepala Puskesmas Petang I)

Dari sudut pandang informan, sarana dan prasarana fisik puskesmas dikatakan sudah baik dan lengkap.Namun berbeda halnya dengan sudut pandang petugas puskesmas. Masih terdapat beberapa kekurangan puskesmas dalam memberikan layanan PPIA dari sudut pandang petugas puskesmas seperti keterlambatan ketersediaan reagen dan keterbatasan SDM kesehatan, dalam hal ini keterbatasan jumlah konselor.

Sesuai dengan hasil penelitian di Kota Yogyakarta dan Makassar, terdapat beberapa kendala dalam pelaksanaan program PPIA terkait dengan kesiapan layanan seperti kurangnya 
sarana dan prasarana fisik dan kekurangan ketersediaan SDM yang perannya sangat berpengaruh terhadap upaya pelaksanaan PPIA (Asmauryanah dkk, 2014; Latifah dkk, 2014). Selain sarana dan prasarana fisik, keterbatasan sumber daya manusia juga mempengaruhi layanan PPIA komprehensif. Sesuai dengan hasil penelitian di Surabaya, ketersediaan fasilitas sarana dan prasarana masih kurang, begitu pula dengan ketersediaan petugas kesehatan masih kurang sehingga mempengaruhi layanan PPIA komprehensif (Widiyasari dkk, 2014).

Hasil wawancara di atas sesuai dengan penelitian di Uganda yang menyebutkan bahwa kurangnya sumber daya manusia merupakan salah satu penghambat dalam memberikan layanan PPIA komprehensif. Kurangnya petugas kesehatan ditambah banyaknya jumlah pasien mempengaruhi pelaksanaan layanan PPIA komprehensif yang diberikan oleh petugas kesehatan (Gourlay et.al, 2013). Berdasarkan hasil wawancara, keterbatasan sarana dan prasarana fisik serta keterbatasan SDM kesehatan sejauh ini dapat diatasi sehingga tidak menghambat informan dalam mengkases layanan PPIA.

\subsection{Komunikasi dan Sikap Petugas}

Komunikasi dalam hal ini terkait dengan pemberian informasi kepada informan mengenai infeksi HIV-AIDS dan layanan PPIA. Sementara sikap terkait dengan cara petugas kesehatan menyampaikan informasi layanan PPIA kepada informan. Dari pemahaman informan terhadap informasi infeksi HIV-AIDS yang diberikan petugas kesehatan, informan mengatakan mengetahui infeksi HIV-AIDS hanya sebatas cara penularan dan cara pencegahan infeksi HIVAIDS.

"Tawang tentang virus gen, penularane lewat hubungan seksual, cara pencegahane nganggo kondom (tahu tentang virus saja, penularannya melalui hubungan seksual, cara pencegahannya menggunakan kondom)" (Pernyataan informan R-02)

Terkait informasi mengenai layanan PPIA, ketiga informan dirujuk ke Rumah Sakit Kapal untuk mendapatkan informasi lebih lengkap mengenai PPIA komprehensif dan pemeriksaan selanjutnya.

"Dibilang ga bole dikasi ASI, yaa lebih jelasnya disuruh ke Rumah Sakit Kapal" (Pernyataan informan R-01)

Secara garis besar, sikap petugas puskesmas terkait cara menyampaikan informasi layanan PPIA dari sudut pandang informan dikatakan baik dan ramah oleh sebagian besar informan.

"Luung, halus, ramah, ten sanget saklek (bagus, halus, ramah, tidak terlalu saklek)" (Pernyataan informan R-02) 
Sudut pandang berbeda disampaikan salah seorang informan mengenai sikap petugas. Informan mengatakan ada petugas puskesmas yang sikapnya baik tetapi masih ada pula petugas yang sikapnya kurang baik kepada informan. Sikap petugas yang dikatakan baik oleh informan adalah petugas kesehatan yang selalu menyapa pasiennya saat bertemu.

"Kadang ada yang tidak bagus, kadang ada yang bagus. Kalau sama Bu Agungnya bagus, jadi senang terus dia nyapa" (Pernyataan informan R-03)

Terdapat perbedaan sudut pandang informan mengenai sikap petugas kesehatan, dimana ada petugas kesehatan yang baik dan ramah saat berinteraksi dengan pasien tetapi ada pula petugas kesehatan yang dianggap kurang baik saat berinteraksi dengan pasien karena tidak selalu menyapa pasien. Penelitian di Uganda mengungkapkan bahwa salah satu permasalahan dalam pelaksanaan program PPIA adalah terkait kurang optimalnya komunikasi antara penyedia layanan dan ibu hamil, menyebabkan ibu hamil HIV positif malas untuk datang dan melanjutkan terapinya (Duff et al, 2010). Sesuai dengan hasil wawancara dalam penelitian ini, kurang optimalnya komunikasi dan sikap petugas terkait pemberian informasi mengenai layanan PPIA dapat mempengaruhi pemahaman dan keinginan ibu hamil HIV positif untuk melanjutkan perawatan PPIA komprehensif.

\subsection{Waktu Tunggu}

Waktu tunggu untuk mendapatkan layanan PPIA di puskesmas relatif cukup lama yaitu kurang lebih satu jam karena waktu tunggu dipengaruhi oleh jumlah pasien dan tindakan yang diberikan kepada pasien.

"Lama, sampai sejam kayaknya soalnya pas cek lab itu lama soalnya antriannya lama"

(Pernyataan informan R-03)

Penelitian di Uganda mengungkapkan bahwa permasalahan terkait panjangnya waktu tunggu saat terapi menyebabkan ibu hamil HIV positif menjadi malas untuk datang dan melanjutkan terapinya (Duff et al, 2010). Meskipun dalam penelitian ini waktu tunggu informan untuk mendapatkan layanan PPIA sejak datang hingga mendapatkan layanan memerlukan waktu yang cukup lama yaitu kurang lebih satu jam, waktu tunggu tersebut tidak menghambat informan untuk mengakses layanan PPIA di puskesmas.

\subsection{Pendampingan dalam Pelaksanaan Layanan PPIA}

Pendampingan merupakan proses fasilitasi guna membantu, mengarahkan, dan mencari jalan keluar terhadap berbagai permasalahan yang dihadapi dengan cara mendampingi. Peran 
pendamping dapat berfungsi sebagai fasilitator, broker, mediator, pembela, serta sebagai pelindung (Latifah dkk, 2014). Pendampingan dalam pelaksanaan layanan PPIA adalah memfasilitasi ibu hamil HIV positif untuk melaksanakan perawatan PPIA secara komprehensif. Pendampingan dirasa perlu bagi seseorang dengan HIV terutama bagi ibu hamil HIV positif terkait dengan adanya stigma di masyarakat terhadap seseorang dengan HIV, sehingga pendampingan diharapkan dapat mengurangi tekanan psikis dan sosial yang timbul terkait status HIVnya dan tetap melanjutkan terapi secara komprehensif. Pendampingan ibu hamil HIV positif di Puskesmas Kabupaten Badung berbeda-beda di masing-masing puskesmas.

Di Puskesmas Petang I, setelah hasil tes HIV pasien di puskesmas keluar dan didapatkan hasil yang reaktif, pasien dirujuk ke RS Kapal untuk pemeriksaan selanjutnya. Tidak ada pendampingan khusus saat pasien melakukan pemeriksaan selanjutnya di RS Kapal, kecuali ada permintaan dari pasien untuk diantar. Informan R-01 mengatakan datang ke RS Kapal diantar oleh bapak kandungnya, tidak ada petugas yang mendampingi.

"atehne sareng bapak tyang gen (dianter sama bapak saya saja)" (Pernyataan informan R-01) "Jika ibu hamil itu positif, tentu dia akan dirujuk ke RS Kapal. Tidak ada yang khusus mendampingi, kecuali kalau pasiennya minta diantar ke rumah sakit."

(Pernyataan Kepala Puskesmas Petang I)

Di Puskesmas Petang II, jika hasil tes HIV pasien di puskesmas keluar dan hasilnya reaktif pasien dirujuk ke RS Kapal untuk pemeriksaan selanjutnya dan didampingi oleh seorang jejaring LKB. Pendampingan jejaring LKB dilakukan agar pasien benar-benar melakukan pemeriksaan selanjutnya di RS Kapal. Informan R-02 mengatakan diantar ke RS Kapal hanya satu kali saja yaitu saat pertama kali melakukan pemeriksan ke RS Kapal.

"nggih, maan atehne ke RS Kapal cepok gen nike (iya, dapat diantar ke RS Kapal hanya satu kali saja)"

(Pernyataan informan R-02) "setelah hasil keluar dan hasilnya positif kita sarankan ke pasien untuk melanjutkan pemeriksaan ke rumah sakit dan didampingi oleh LKB. Kita punya jejaring LKB yang mengantar satu biar dia benar-benar ke rumah sakit untuk pemeriksaan selanjutnya"

(Pernyataan Petugas Puskesmas Petang II)

Sementara di Puskesmas Mengwi II, setelah hasil tes HIV keluar dan hasilnya reaktif informan akan dirujuk ke RS Kapal untuk pemeriksaan selanjutnya dengan didampingi oleh Lembaga Swadaya Masyarakat (LSM). Informan R-03 mengatakan melakukan pemeriksaan selanjutanya di RS Kapal didampingi oleh salah satu LSM di wilayah Mengwi II.

"iya, sama Tu Ajinya dianter ke RS Kapal." (Pernyataan informan R-03) 
"begitu pasien ditemukan reaktif, didampingi sama LSM kemudian kita rujuk dia ke rumah sakit."

(Pernyataan Petugas Puskesmas Mengwi II)

Penelitian di Sub-Sahara Afrika dan Zimbabwe menunjukkan bahwa keberhasilan program PPIA komprehensif salah satunya dipengaruhi oleh adanya follow-up dan pendampingan berkelanjutan selama pelaksanaan program PPIA komprehensif setidaknya selama 24 bulan setelah kelahiran bayi (Homsy et al, 2004; Perez et al, 2004). Berdasarkan hasil wawancara, terdapat pendampingan yang beragam di masing-masing puskesmas bagi ibu hamil HIV positif dalam menjalani perawatan PPIA komprehensif oleh petugas kesehatan yang disebabkan oleh tidak adanya Standar Pelayanan Minimal (SPM) program PPIA terkait pendampingan bagi ibu hamil HIV positif.

\section{PENUTUP}

PPIA komprehensif merupakan salah satu program yang efektif dalam mencegah penularan HIV-AIDS dari ibu ke anaknya sehingga program PPIA digalakkan oleh Pemerintah untuk menurunkan angka HIV-AIDS bagi ibu maupun anaknya. Aspek kesiapan layanan merupakan salah satu aspek yang sangat berpengaruh dalam pelaksanaan program PPIA komprehensif. Aspek kesiapan layanan terkait dengan kurangnya komunikasi petugas dalam memberikan informasi PPIA komprehensif dan tidak adanya pendampingan dalam pelaksanaan layanan PPIA sehingga mempengaruhi pemahaman dan keinginan ibu hamil HIV positif untuk tidak melanjutkan perawatan PPIA komprehensif.

\section{DAFTAR PUSTAKA}

Anindita M, Shaluhiyah Z, Suryhoputro A. Non Disclosure of HIV Positive Status of Women to Their Partner: Implication For PMTCT in Central Java Indonesia. Sci Journal Med Clinical Trial 2013; 2013: 1-6.

Asmauryanah R, Amiruddin R, Ansar J. Pencegahan Penularan HIV dari Ibu ke Bayi di Puskesmas Jumpandang Baru Makassar. Makassar, 2014.

Direktur Jenderal Bina Gizi dan KIA. Integrasi Program PPIA (PMTCT) di Pelayanan Kesehatan Ibu dan Anak. In: Peranan Bidan dalam Mendukung Pencegahan Penularan HIV dari Ibu ke Bayi. Jakarta, 2012.

Duff P, Kipp W, Wild TC, et al. Barriers to Accessing Highly Active Antiretroviral Therapy by HIV-Positive Women Attending An Antenatal Clinic in A Regional Hospital in Western Uganda. Journal Int AIDS Soc 2010; 13: 37. 
Gourlay A, Birdthistle I, Mburu G, et al. Barriers and Facilitating Factors to The Uptake of Antiretroviral Drugs for Prevention of Mother-to-Child Transmission of HIV in SubSaharan Africa: A Systematic Review. Journal of the International AIDS Society 2013; $1-21$.

Homsy J, King R, Balaba D, et al. Traditional Health Practitioners are Key to Scaling Up Comprehensive Care For HIV/AIDS in Sub-Saharan Africa. AIDS 2004; 18: 1723 1725.

Kemenkes RI. Peraturan Menteri Kesehatan Republik Indonesia No. 97 Tahun 2014 Tentang Pelayanan Kesehatan Masa Sebelum Hamil, Masa Hamil, Persalinan, dan Masa Sesudah Melahirkan, Penyelenggaraan Pelayanan Kontrasepsi, serta Pelayanan Kesehatan Seksual.

Kemenkes RI. Peraturan Menteri Kesehatan Republik Indonesia No. 51 Tahun 2013 Tentang Pedoman Pencegahan Penularan HIV dari Ibu ke Anak. 2013; 1-43.

Kemenkes RI. Rencana Aksi Nasional Penularan HIV Dari Ibu ke Anak (PPIA) Indonesia 20132017.

Kemenkes RI. Pedoman Nasional Pencegahan Penularan HIV Dari Ibu Ke Anak (PPIA). Edisi Kedua. Jakarta, 2012.

KPA. Situasi Kasus HIV/AIDS di Provinsi Bali. 2016.

Latifah D, Mulyana N. Peran Pendamping Bagi Orang dengan HIV/AIDS (ODHA). In: Prosiding KS : Riset \& PKM. 2014, pp. 306-311.

Perez F, Mukotekwa T, Miller A, et al. Implementing A Rural Programmeme of PMTCT of HIV in Zimbabwe: First 18 Months of Experience. Trop Med Int Heal 2004; 9: 774-783.

Ritzer J, Douglas J. Teori Sosiologi Klasik Sampai Perkembangan Mutakhir. Yogyakarta: Kreasi Wacana, 2010.

Wahyuni S. Kepatuhan Ibu Pada Kehamilan, Persalinan dan Nifas Dalam Pelaksanaan Program Pencegahan Penularan HIV. Jurnal Kebidanan dan Keperawatan 2016; 12: 38-45.

Widiyasari E, Shaluhiyah Z, Margawati A. Implementasi Integrasi Program Prevention of Mother to Child HIV Transmission (PMTCT) dengan Layanan Antenatal di Puskesmas Wilayah Kota Surabaya. Jurnal Manajemen Kesehatan Indonesia 2014; 10-18. 